\title{
Research on the reform of management system of higher vocational education in China based on personality standard
}

\author{
Ying Ling $^{1} \cdot$ Soo Jin Chung ${ }^{2} \cdot$ Liwen Wang $^{1}$ \\ Accepted: 3 February 2021 / Published online: 26 February 2021 \\ (C) The Author(s) 2021, corrected publication 2021
}

\begin{abstract}
With the rapid development of Higher Vocational Education in China, the main objective is to improve the quality of Higher Vocational Education in an all-round way. For a long time, higher vocational education has been using the knowledge-based education mode of general higher education or secondary vocational education. Until the early 1990s, the ability-based education model was gradually introduced. The understanding and research of higher vocational education should not be confined to the interior of education. Many policies and measures to accelerate development have been introduced, and the scale of vocational education has been expanding in recent years. Higher vocational education in China has become an important part of higher education. It is an important type of higher education and a high level of vocational education. In order to cultivate the sound personality of students in higher vocational colleges, it is necessary to establish a personality-based education model. Realize the innovation of talent training mode and the quality improvement of personnel training. Meeting the new normal of the innovationdriven society, the demand for high-quality technical skills is required. It is a major practical problem facing the current construction of a modern vocational education system.
\end{abstract}

Keywords Vocational education $\cdot$ Personality standard $\cdot$ Education mode $\cdot$ Talent training

\section{Introduction}

With the Chinese government attaching great importance to vocational education, many policies and measures have been introduced to accelerate the development of Vocational education. In recent years, the scale of development of vocational education has been expanding (Cevik, Perkmen, Alkan, \& Shelley, 2013). Higher vocational education has become an important force in the popularization of higher education in China, but its social recognition is still low. China's economic system reform will enter a period of industrial restructuring (Volodina, Nagy, \& Olaf, 2015). Similarly, the mode of production of social material life determines that the structure of higher education must be adapted to it. Education is an important part of people's livelihood and plays a fundamental role in improving people's livelihood. Education is closely related to people's livelihood, that is, people's rights and interests in

Soo Jin Chung

sujinjeong013@gmail.com; sj@wku.ac.kr

1 Zhejiang Industry Polytechnic College, Shaoxing 312000, China

2 Wonkwang University, Iksan-si 54538, South Korea survival, life and development (Ding, Salyers, Kozelka, \& Laux, 2015). Higher vocational education in China has become an important part of higher education. It is an important type of higher education and a high level of vocational education. A sound vocational education system is of great significance for promoting vocational education and teaching, achieving vocational education goals, improving the skills and professional qualities of workers, and developing vocational education and social productivity (Sheldon, 2005). Higher vocational education has entered a period of rapid development and has become an important direction and focus of China's higher education cross-century reform and development (Taylor \& Mailick, 2013). In China, Vocational Education is generally carried out in different educational institutes, vocational high schools, secondary schools, and other adult institutions. Besides, those institutes come in various types such as Peasants colleges, Administrative colleges, Distance Education Colleges, and so forth. Statistics state that more than two million people have enlisted their names into Vocational Institutions in China. Initially, those who completed their vocational education were not rewarded by the Chinese Government. However, after several educational reforms, students who completed their graduation in Vocational education were awarded with non-degree diplomas (Potter et al., 2011). Towards the end of twentieth 
century, China witnessed the growth of new educational institutions which gradually increased the demand for vocational institutions thereby localizing vocational education. Several educational reforms defined the characteristics of vocational education as 'localism' and 'vocationalism' which can be evident in the educational program structure and the curriculum. All the vocational education programs in China are administered locally and they hold a dynamic relationship with the society. Moreover, it is believed that vocational training schools maintain their dynamic relationship with the employers which will help the former to change according to the environment (Longo, Gunz, Curtis, \& Farsides, 2016; Schulte, 2013; Tiwari, Tiwari, Santhose, Mishra, Rejeesh, \& Sundararaj, 2021; Sundararaj \& Rejeesh, 2021; Sundararaj, 2016; Sundararaj, 2019a, b; Rejeesh \& Thejaswini, 2020).

In the beginning, students who completed their vocational education were employed at local level soon after their education. Students with low grades were admitted to vocational programs and generally led to jobs with low pay such as operators, technicians, and so forth. At the same time, the economic expansion of China influenced the vocational educational institutions, their policies as well as practices. Gradually, Vocational education institutions turned their focus from enrolled candidates to the quality of the programs delivered. In other words, China's higher vocational education, while the number is developing, aimed to seek quality improvement. To comprehensively improve the quality of other vocational education, it is necessary to carry out reform and innovation of the education model. For this, the Chinese government conducted conferences nationally that focused on the "learning, production, research combination, and cooperation" (Potter et al., 2011). In addition to above, the whole vocational education system came up with the basic principles which concentrated on "employment-oriented, service-aimed, production-learning-research combined" (Potter et al., 2011). After 2004, Chinese Vocational Education Institutions shifted their focus to the curriculum and instructional model reform. It was stressed that vocational education should come with a standardized curriculum and more weight should be placed on practical training as well which will ultimately allow the students to transcend their limitations of subject-based curriculum.

Vocational Education Institutions of China are highly shaped by the Chinese Government and of course the existing educational agencies. It is claimed that Chinese Government provided adequate fund and support to develop multiple vocational programs, hire faculties, and set admission criteria to the students. In short, the government supports the public in each and every step. To improve the national competition as well as to achieve the goals of vocational education, MOE of China implemented national policy for education which stressed on quality, expansion, efficiency, restructuring, regulate and reform the existing programs. Hence it can be argued that national policy played an essential role in developing China's vocational education towards achieving global economy and modernization. Additionally, the Chinese government funds the vocational education sector as there had to develop business and create opportunities for unemployed citizens. It was noted that many areas of China were under unemployment and needed attention as it immensely affected the economy of the country. Apart from the above reasons, Chinese educational system had several flaws and weaknesses which required high attention so that it helps the people, workers, or employees to meet their needs. In this context, Chinese government aimed to have a quality education system which allowed them to implement reforms to the existing system. According to Potter et al. (2011), the main reason behind unemployment in China is Skill Mismatch. Students will be taught a particular skillset which does not help them at workplace in real. Due to this reason, students have found it difficult to shunt for the jobs in the market.

Apart from all the above, Chinese market is open for multiple manufacturing jobs for which highly skilled workers or employees are essential. Only providing vocational education to the poorly educated people will help the government to increase the demand for economy. Along with this, the employees are demanding to provide additional trainings to enhance their skills and knowledge which will ultimately increase their demand in the marketplace. As a reform, the government ensured to deliver quality trainings to the students so that the quality of the vocational education system is always ensured (Xiong, 2011). The Chinese government encouraged business enterprises to conduct trainings for the students so that they improve their skill levels with regard to their work domain. By doing so, the workers are felt motivated to accomplish the desired tasks assigned. Thus, the government came up with few initiatives such as conducting training to the employers, establish training for apprentice employers. Furthermore, government aimed to conduct collaborative programs between educational institutions and enterprises which develops new skilled workforce suitable to the marketplace. Gradually, greater focus from agriculture to vocational training has been witnessed in China, especially in the field of economics, finance, and administration. By doing so, the Chinese government had been successful in strengthening the literacy rate (Xiong, 2011).

The quality of the education receive in vocational educational institutions was always in disparity as the number of teachers were less in number to conduct the trainings. Due to this shortage of skillful teachers, the quality of the education was compromised. These reasons led to a new vocational education law which stressed on providing $20 \%$ of the annual education budget to the Vocational Educational Institutions. Besides, the teachers who were employed had lack of experience to provide practical knowledge to the students as most of 
them recently completed their graduation (Xiong, 2011). Hiring underqualified teachers can affect the expansion of China's national economic development. With regard to hiring teachers, the Vocational Educational Law allowed some kind of relaxation to the institutions by permitting them to employ part time teachers, although it is not a permanent solution.

As time progressed, China came up with new reforms, especially in the field of teacher education that addressed existing concerns with respect to hiring professional and qualified teachers (Xiong, 2011; Potter et al., 2011). It is argued that teachers should receive and undergo continuous trainings throughout their career so that they will get the opportunity to upgrade and upskill themselves as per the market needs and demands.it is suggested that teachers should mandatorily undergo $240 \mathrm{~h}$ of training once in five years and simultaneously work for two months in the same industry once in every two years. By doing so, the teachers will received adequate exposure to practical experience which ultimately improves the quality of vocational training. Keeping this in mind, the new vocational education structure had been built which managed to match with the existing one (Baartman, Gulikers, \& Dijkstra, 2013). The essential role of education is to transform and construct the subjective world of people and directly point to the spiritual activities of people. The starting point and the foothold point to specific real people, and the people are the personal experience and direct beneficiaries of education and people's livelihood (Heers, Van Klaveren, Groot, et al., 2014). Actively developing higher vocational education is an important feature of the development of higher education in the world in recent decades. Many industrialized countries are adapting to economic restructuring and rapid economic developments during the economic takeoff stage (Elffers \& Oort, 2013). After several years of hard work, the higher vocational colleges have introduced and created many school-running models and training models that have significant effects and meet market needs (Perkmen \& Sahin, 2013). If we examine the development of Higher Vocational Education from the perspective of lifelong education, it will open a broad vision for the development of Higher Vocational education. It is conducive to the establishment of a sound system of higher vocational education and the establishment of a mechanism for the sustainable development of Higher Vocational education. To realize the innovation of personnel training mode and the improvement of personnel training quality (Asplund \& Kilbrink, 2016). To meet the needs of high-quality technical and skilled personnel in the new normal society driven by innovation. It is a major practical problem in the construction of modern vocational education system. The emergence of education and people's livelihood in China is the product of the changes of social environment and times, and is also the result of the stimulation and growth of people's educational needs (Niemi \& Kurki, 2014).

\section{Literature Review}

\section{Vocational Higher Education}

Vocational Higher Education is considered as important for several reasons. First and foremost reason is that it helps to build attractive infrastructure that suits the modern life, repair and maintain the equipment, provide hospitality services, develop technological innovations, and so forth with the help of skillful and knowledgeable people. For instrumental reasons, vocational education is considered essential. Vocational education is considered as a concept that is a combination of inherent and developed values that are associated with an individual's occupation. The occupation of an individual allows him or her to practice and be well- versed in their skilled work. There had always been a debate on the significance of vocational education and its high need to reform the existing laws. As it is already known, Vocational education adds an additional colour to the economy of any country and hence is always connected with economic competitiveness (Fuller, 2015). It is claimed that those countries with effective vocational education system become successful in the global competition. Vocational education is also considered as a consistent pathway for those who have dropped off from their schooling. Different models of vocational training and education has been recognized in different countries. It is estimated that China is highly in need of skilled workforce or laborers which supports the economic condition of the country (Xiong, 2011). Even though vocational education system had been developed and reformed, China still faces inadequacy in producing skilled employers. Amongst 270 million workers, 87 million workers are considered to be well qualified with desired skills set which constitutes only $32 \%$ of the entire workforce (Xiong, 2011).

In order to prepare high skilled employees, higher vocational education system existing in China needs to be change their developmental path which will focus on technical aspects such as methods of reforming, hiring, teaching-learning methods, and so on. The educational model has gradually changed from the knowledge-based education model to the ability-based education model, which has resulted in a number of new educational models, such as the simulation company (Routledge, Wildschut, Sedikides, \& Juhl, 2013). Governments in all countries regard the development of education and human resources as the preferred strategy to enhance comprehensive national strength and international competitiveness, and as the key support system for sustainable socio-economic development (Sovet, Park, \& Jung, 2014).

\section{Vocational Education Psychology}

Education can improve people's material and spiritual living standards, help to improve the external conditions of 
individual survival and development, and also help to enhance the ability of personal happiness (Reichl, Wach, Spinath, Brünken, \& Karbach, 2014). After a large number of enrollment expansions, vocational colleges have solved the problem of students' way out, so that the concept of "employmentoriented" is understood as "vocational education is employment education" (Hastrup, Kongerslev, \& Simonsen, 2018). Holtrop D pays great attention to professional ethics education in vocational education, which is a very important part of his modern educational thought (Holtrop, Born, \& De Vries, 2015). Stewart A J and others believe that those who advocate vocational education must also pay attention to professional ethics. The basic requirements of professional ethics education are proposed (Curtin, Stewart, \& Ostrove, 2013). Hannes pointed out that vocational education should pay special attention to professionalism and professional ethics (Zacher, 2014). This has an important impact on promoting the national spirit and cultivating the social responsibility of the younger generation. Education is at the foundation of the formation of comprehensive national strength. The strength of national strength is increasingly dependent on the quality of workers, depending on the quality and quantity of all types of talent.

According to Merriam Webster Dictionary (2012), Vocational Psychology is referred to as "application of psychological principles to the problems of vocational choice, selection and training". It is understood that Vocational Psychology is deep-rooted discipline which is covered under counselling psychology. The main responsibility of a vocational psychologist is that he or she analyses the work decision across the ages. Later, they support the common public to make accurate decisions related to their work. For instance, they help the individuals to make important decision with respect to their career, mange the career, adopt the work changes, and finally plan retirement (Blustein, Ali, \& Flores, 2019). Surprisingly, these psychologists pay more attention to the individual's choice with respect to their working environment. They try to focus on the individual rather than on the organization. It is recorded that vocational psychology as a concept began flourishing in the twentieth century when they were given chance to establish and develop projects related to depression. It is explained that these projects strived hard to help those Veterans of World War II who had to build strong workforce with the help of Soviet.

Gradually, vocational psychology started influencing counselling psychology (Fouad \& Iackson, 2013). Multiple vocational psychologists stated that broader analysis and recommendations with respect to vocational education system will help the future researchers contribute to the existing literature. Besides, it is found that the changes in nature of work largely impact the psychology of an individual. According to Blustein, Ali, and Flores (2019) individuals who had been working consistently with appropriate incomes began finding themselves out of the system or work as they lacked adequate skills to engage with their new occupation which emerge gradually.

\section{Challenges in Developing Higher Vocational Education in China}

It is claimed that the coming generation of China will be more skilled, educated and proficient in the field of vocational education. China witnessed rapid development in the field of primary education during the period from 1980 to 2000. Initially, schools were reopened for both primary as well as secondary students. Later, education was made compulsory until 9 years of age with 6 years of primary and 3 years of secondary education. This primary school system turned out to be a universal system with more than $92 \%$ of enrollment by the year 2013 (Yaun, 2013). Slowly, China moved from higher education to mass higher education where in the students were sent to outskirts to carry out their higher studies. By doing so, universities across the world had enrolment with Chinese students on top. Hence it can be concluded that China slowly developed and expanded education from primary level to secondary level, now being the biggest educational system in the world. This journey had not been easy at all. The Chinese government and people had to face several challenges with respect to teaching-learning standards, unemployment problems, equity problems, national framework, curriculum, regional disparities, and so forth. Most importantly, China's quality of education was found to be low which eventually led to disparities in the availability of facilities, teachers, and others.

Slowly, the Chinese government expanded their resources by means of funding. Highly skilled teachers were hired in rural areas which encouraged subsidizing fee for compulsory education, providing scholarships to the students, and pair the schools with each other so that it improves teaching (Stewart, 2015). By the end of twentieth century, curriculum was reformed to suit the modern life. The curriculum inculcated modernized teaching methods which had more of practical side so that the students get great exposure and be able to apply the learnt skills. Simultaneously, Vocational Education also grew hand-in-hand with the general education. Although, the policy of vocational education came into existence in 1960 , it was rejected as it promoted social differentiation. Within a decade, tremendous changes in the field of Vocational Education had been witnessed with the expansion of vocational education. History says, China provides vocational education to the students via secondary and territory schools (Stewart, 2015).

The Chinese Vocational Education System although has several strengths, comes with many challenges as well. First challenge faced is the narrowness of the curriculum designed. In other words, the curriculum focuses on entry level skills students which fails to provide an in-depth knowledge about the future direction in terms of career (Stewart, 2015). Further, 
curriculum development does not seem to be designed with the most advanced companies or leading edges of the economy in mind. Second challenge faced is that they maintain weak connections with existing industry experts. Although the building seems to be modern, equipment and other facilities are not modern (Yu, 2005). More importantly, Vocational Educational Institutions are in no way connected to foreign companies which would have implemented international standards. It is also important to note that, Vocational Education is considered to occupy a low status within the mind of common public. The other challenges faced by Chinese Vocational Education Institutions include mismatch between employer's needs and employees capabilities and skills, underdeveloped teaching faculties, and so forth (Stewart, 2015).

\section{Materials and Methods}

China's current higher education system is roughly divided into two major systems: general higher education and higher vocational education. The main body is the general higher education system, and the higher vocational education is in a lower status. The adjustment and reform of the structural system of higher education has accelerated markedly, resulting in large social repercussions. Several concepts related to the personality-based education model of higher vocational colleges are personality, education model, and personality-based education model (Tolentino et al., 2014). China's higher vocational education is in an important period of development opportunities, and social economic and technological development is undergoing historic changes and leapfrogging. The realization process of people's livelihood is a historical process in which people's needs are satisfied, strive for independent liberation, and realize human freedom and all-round development (Cai et al., 2015). With the change of government functions and streamlining of institutions, enterprises will become the main body of legal entities that operate autonomously. The relevant ministries and commissions of the Faculty have gradually lost the ability to undertake higher education, so that the sections are divided and repeated. Because each person's genetic quality, especially social practice activities are different. So that the personality tendencies and personality psychological characteristics among different people are also different, thus forming different personalities. The goal of building a well-off society in an all-round way and speeding up socialist modernization is put forward. It not only creates an external environment for the development of Higher Vocational education, but also provides an internal impetus for the reform of Higher Vocational education.

Studying the educational model is helpful to deal with various educational relations and optimize the structure of educational activities. The orientation and uniqueness of educational mode are determined by certain educational theories or ideas. Due to the impact of Western values, the integration of multi-cultures has made everyone in today's society have the criteria to measure value, resulting in great differences in the judgment of value. Therefore, in the process of college students' employment, there are also diversified value orientations. Enterprises keep on changing their needs of employment every now and then due to which colossal amount of data is produced. For this reason, there is an urgent need to continuously explore and gather experience in the field of construction. The network structure system of vocational education management is provided in Fig. 1.

The value of higher education itself is severely challenged. The essence of international competition is the contest of comprehensive national strength based on science and technology and based on economic strength. Some people are defined from the perspective of educational methods. Teachers are coordinated in different educational stages according to educational purposes and educational tasks, and are formed in the process of applying various educational methods. The specific people of contemporary people's livelihood based on reality contain human nature, social attributes and spiritual attributes. People have a purposeful existence, and the purpose of human beings is especially respected in contemporary people's livelihood. Many people cannot correctly understand the social function and value of higher vocational education. There is still no clear understanding of why it is necessary to develop higher vocational education and why it is necessary to study higher vocational education (Nilforooshan \& Salimi, 2016). Colleges and universities are required to cultivate innovative talents with the unity of scientific literacy and humanistic spirit, and thoroughly change the past examination-oriented talents with too narrow professional knowledge. Many higher vocational colleges still run higher vocational education according to the mode of academic elite education. The content

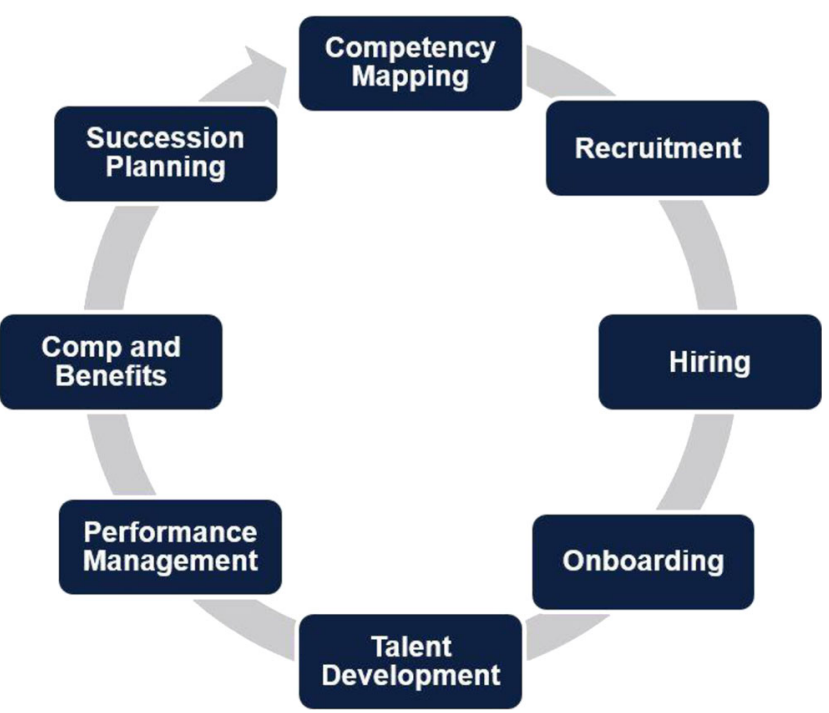

Fig. 1 The network structure system of vocational education management for talents 
of education is divorced from the reality of social profession and should gradually become the creator of profession. Any educational model should point to certain educational objectives, that is, the higher vocational education model is designed and constructed to achieve the goal of training talents in Higher Vocational colleges.

Besides the external and objective factors such as social and economic development and employment policy, college students' view of career choice is considered to be one of the significant reasons. The risk index system of College Students' entrepreneurship team is established, and the risk is evaluated by analytic hierarchy process. Besides, construction of weight judgement matrix is also found simultaneously. As shown in Fig. 2, the relationship between weight and evaluation value is explored. While Fig. 3 showcases the relationship between financial risk weight and evaluation value.

Economists believe that human resources, rather than capital and natural resources, will ultimately determine the characteristics and pace of a country's economic and social development. Educational resources have been fully utilized and the efficiency of running schools has been greatly improved. It strengthens the vitality of the school to run independently for the society, and promotes the school to serve the local economic and social development better. Any educational model has a unique educational structure and an operational sequence reflecting the logical process of educational activities. The personality-based education model is based on the educational thought of the all-round development of human beings, personality theory and humanistic psychology. In order to cultivate students' independent personality and rich personality as the value orientation, a relatively stable educational process and its methods and strategies system are formed in the process of education. In the context of economic globalization, more and more countries recognize that financial resources or natural resources alone cannot be in a

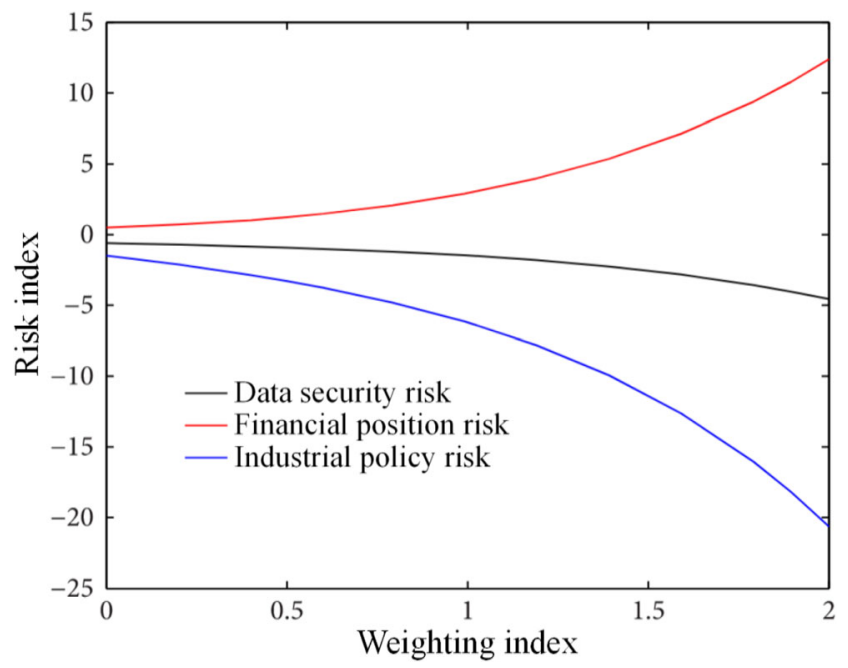

Fig. 2 Relationship between weight value and evaluation value

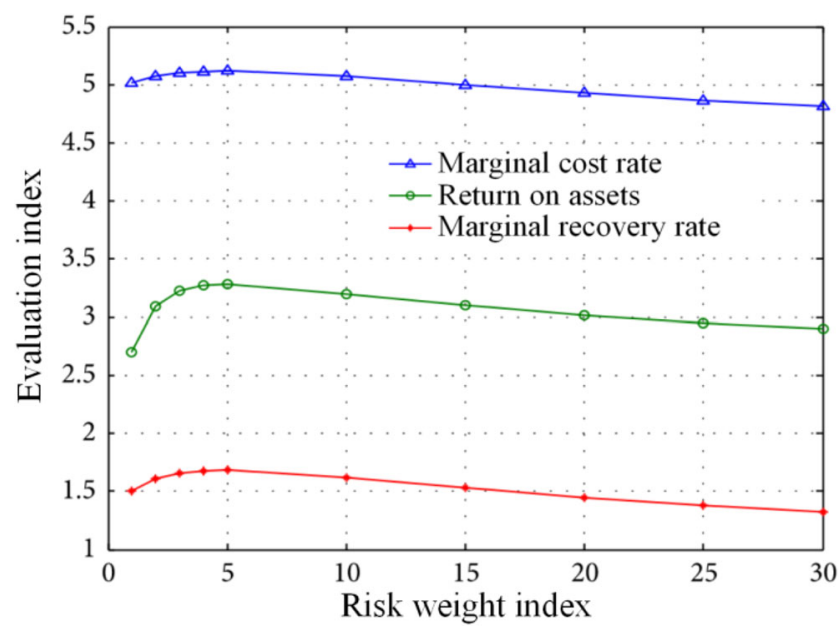

Fig. 3 Relationship between financial risk weight and evaluation

favorable position to occupy international competition. In the human demand structure system, meeting the needs of human survival, that is, physical and safety, is the most basic need and is an unquestionable right. As the existence of a higher life body in nature, man has no living people, and all other people's livelihood activities cannot be discussed. The personality-based education model is not a specific education model, but a general term for a people-oriented education model.

It is claimed that releasing personal information will result in forming one's own voice in the network with respect to non-directional dissemination of information. It is also considered that the expression of netizens' opinions will be more fluent and open than ever. Considering the symmetry requirement of big data letters, when the network capacity relative bandwidth demand is relatively large, the symmetric traffic demand will be tree-like. The corresponding parameters of different business items are shown in Table 1.

The values of students' learning and the formation of learning emotions have brought education awareness to a higher level. The information entropy after attribute classification is:

$k=\sqrt{\frac{\xi_{f s}}{\xi_{\text {amp }}}} \sqrt{\frac{M_{1} M_{2} N}{2 \pi}} \frac{1}{d^{2}{ }_{\text {toBS }}}$

Personalized teaching uses a new educational concept and teaching methods, which differs from traditional teaching

Table 1 Network cost of symmetric services

\begin{tabular}{llllll}
\hline Business type & 1 & 2 & 3 & 4 & 5 \\
\hline Genetic algorithm & 24.016 & 35.386 & 25.841 & 17.558 & 24.008 \\
Single Domain & 35.415 & 33.277 & 22.879 & 21.374 & 25.317 \\
Hubrid & 20.401 & 42.605 & 14.612 & 24.823 & 30.504 \\
\hline
\end{tabular}


methods and methods. In the hypothesis test of two independent sample ratios, the statistics used are:

$$
E_{\text {total }- \text { min }}=l\left(E_{\text {elec }} N+E_{D A} N+d^{2}{ }_{t o B S} \sqrt{\frac{2 M_{1} M_{2} N \xi_{f s} \xi_{\text {amp }}}{\pi}}\right)
$$

Can be derived:

$$
S=2 L+W=\frac{c}{2 f \sqrt{\varepsilon_{e u}}}
$$

Substituting data into calculations:

$$
E S_{i}=\sum_{j}\left(1-\sum_{q} p_{i q} m_{j q}\right), q \neq i, j
$$

The personality-based education model is based on a certain theoretical basis. The application of these theories in the education model makes the personality-based education model have a comprehensive theoretical basis. Vigorously developing vocational higher education is an important guarantee for the popularization of higher education in China. The concept of career choices is constantly changing and developing with the changes in the environment of career choice. Employment guidance work of universities as well as colleges can be targeted only if the students understand the concept of employment with respect to education, teaching-learning management, and so forth. The dynamic evolution of assessment system followed in vocational universities and colleges is showed in Fig. 4.

The lag of human capital has caused China to lose two important strategic opportunities in history, and the lag of the establishment of modern education system has hindered the development and accumulation of human resources. Deep

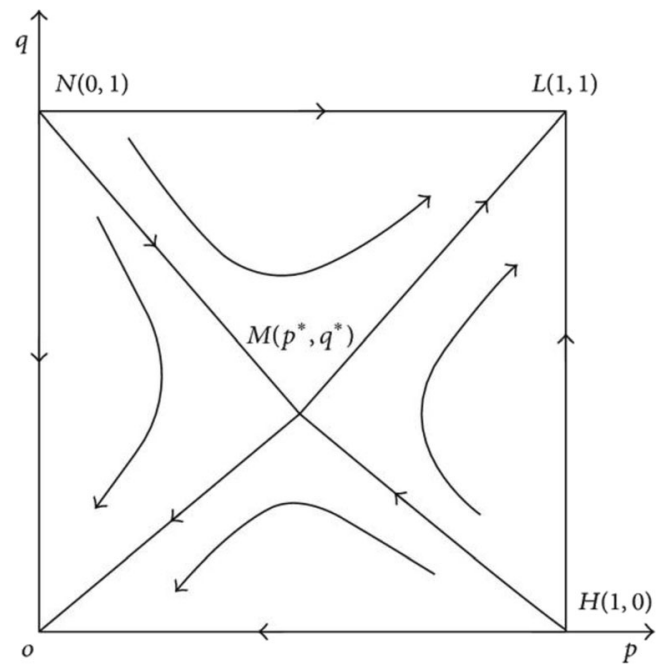

Fig. 4 Dynamic evolution of the vocational education assessment system changes are taking place in China's social life and economic fields. These changes not only form the environmental characteristics of the development of higher vocational education, but also bring opportunities and challenges to the development of higher vocational education. In the management of vocational education, the government clarifies its responsibilities and combines the government's macro-control with market regulation ( $\mathrm{Wu}, 2016)$. It has enhanced the initiative of independent development of vocational schools, making the development of schools more in line with market demand. The improvement of people's cognitive ability and standard of things will enrich the meaning of people's livelihood. According to the classification of educational functions, vocational education and general education are only differences of types, not of levels (2016). The manifestation of vocational higher education abroad is Community University, which has obvious local characteristics. The diversity of educational models is determined by the diversity of the elements and their combinations. The diversity of educational modes is not only the basic requirement of modern education, but also the characteristic of personality-based education mode.

\section{Data Analysis and Discussion}

The rapid development of scientific and technological revolution has brought the traditional production technology system into a new stage of theoretical and technological system. The outstanding performance is that the period from science and technology to product production is shortened and the industrialization of high and new technology is accelerated. When the basic survival problems of the people are solved, their basic development ability and opportunities will be taken into account (Selvarajan, Singh, \& Cloninger, 2016). People not only can survive, but also have the ability to survive. At the present stage, China's high economic development and the continuous upgrading of industrial structure have made vocational education have the realistic needs and foundation of moving up the hierarchy. We should reasonably guide and develop higher vocational education above undergraduate level according to social needs. There are various views and theories on the formation and development of personality in the field of psychology. There are many shortcomings in psychoanalytic theory, and personality is a unified structure. It is an organism with multiple factors and multiple levels, and the development of sound personality. It lies in the comprehensive and coordinated development of the personality structure, not just the one-sided development and improvement of a certain aspect. The development of high-tech industries requires that technicians working in the front line not only have to master more comprehensive theoretical knowledge. It is necessary to be familiar with and master the practical application of high-tech and advanced equipment. At the time of 
assessment, the teacher will verify the score according to the professional post standard, scope of duties and work content of the graduates of this major.

Meet the specific implementation needs of multi-standard data collection, processing and integration, and multidisciplinary education visualization system applications. For example, Table 2 is the survey and statistics of the degree of management education in vocational education. From the table it is understood that 13 individuals are fully aware of the goal of teaching management education in vocational education, 29 of them are partially aware of the goal of teaching management education in vocational education, and 26 of them state that the goal of teaching management education in vocational education is not been implemented in vocational education institutions.

Big data is the foundation of the future of education. It is used to analyze and study the learning problems and knowledge of a certain learner group or individual. It is possible to generate and collect big data in teaching, and the full and effective use of these data by teachers has become an urgent need to explore and practice. In the teaching process, computer software technology was used. An example is presented. This helps to observe the simulation of big data education instructional design from different directions. The experimental results of the three experiments are shown in Fig. 5.

The concept of employment of college students refers to the understanding and views of college students in the study and participation in social practice, and the relatively stable practice of how to treat employment. To measure the training of college vocational education, we can simply write the trend of college students' employment concept as:

$A E_{i}=E S_{i} / S_{i}=\sum_{j}\left(1-\sum_{q} p_{i q} m_{j q}\right) / \sum_{j}$

Initialize through the decision tree classification, calculate the connection weight and threshold, and then assign any value:

$C I_{i}=\frac{\sum_{j}\left(\frac{C_{i j}}{C / N}\right) \ln \left(\frac{C_{i j}}{C / N}\right)}{N \ln (\mathrm{N})}$

The system framework is designed according to the four main levels of infrastructure layer, data layer, platform

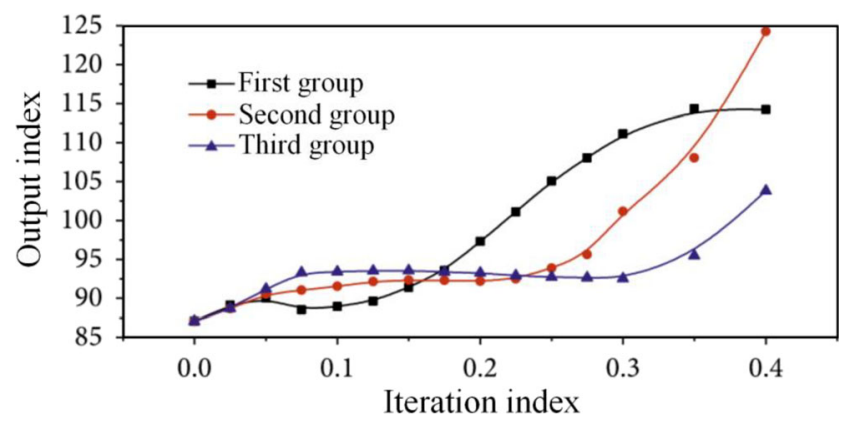

Fig. 5 Iteration value and output relationship

layer and application layer. Provide input samples and expected output:

$P_{\mathrm{i}}=\frac{\mathrm{f}_{i}}{\sum_{i=1}^{N} f_{i}}$

It is found that the current link between higher vocational education and secondary vocational education is not smooth, which has affected the normal development of higher vocational education. The basic entity of character is not a single personality trait, but the entire personality structure. A single personality trait is formed by this. The adjustment of the structure of higher education must be accompanied by the reform of the management system of higher education in order to coordinate healthy development. It is necessary to fundamentally change the situation in which education does not meet the needs of socialist modernization. We must start with the education system and systematically carry out reforms. Technological innovation and the industrialization of hightech also continue to promote the upgrading of traditional industries and the development of professional models (Jiang, 2017). In order to be able to accept higher education, many junior high school graduates would rather choose the path of ordinary high school, which makes the fierce test competition ahead (Venuleo, Mossi, \& Salvatore, 2014). Vocational education must be reformed and innovated in terms of educational objectives and functions, Schoolrunning Modes and levels in order to actively meet the needs of socio-economic and technological development.

Perfect personality has self-realization, which requires full play of human personality. Under the background of economic restructuring, the occupational post structure in modern society presents a dynamic system. In the traditional work of Ideological and political education, direct communication and
Table 2 Survey on the goal of teaching management education in vocational education

\begin{tabular}{llll}
\hline Degree of realization & Fully implemented & Partial implementation & Not implemented \\
\hline Selected number & 13 & 29 & 26 \\
Proportion (\%) & 19.1 & 42.6 & 38.2 \\
\hline
\end{tabular}


dialogue between people make the work direct and realistic. After each parameter adjustment, the data flow quickly reaches a stable state. Initial rotation is too large, which may lead to excessive data flow. Perform three sets of data tests and statistical results, as shown in Fig. 6.

As far as personality-based ideological vocational education is concerned, it is important to measure the success or failure of a work considering the purpose of vocational education at the same time. Learn how to modify the corresponding so that its shape has ideal performance. Energy for states can be defined as:

$Y_{j}(t)=\phi\left(\sum_{i=1}^{n} w_{j i} x_{i}-\theta_{j}\right)$

In the hidden layer to the hidden layer, there is no connection between the visible layers. Then the average time the model is assigned to the visual node is:

$\mathrm{o}_{\mathrm{j}}(t)=f\left(\left[\sum_{i=1}^{n} w_{i j} x_{i}\left(t-\tau_{i j}\right)\right]-T_{i j}\right)$

$F(x)=\frac{1}{1+e^{-a x}}$

Personality is composed of a set of traits. The trait is the basic unit that constitutes personality. The trait determines the specific behavior of the individual. In the most general sense, the three psychological components of cognition, emotion and will are the most basic components of personality. Personalized learning is basically understood as one of the learning styles which allows the learners to adopt to different situations and satisfy the needs of the learners. Besides, it will also allow the learners to enhance the quality of learner's learning process. It is found that the data starts to flow immediately soon after it reaches a consistent state whenever every parameters are adjusted. The initial rotation is too large and may result in excessive data flow. The study conducts data

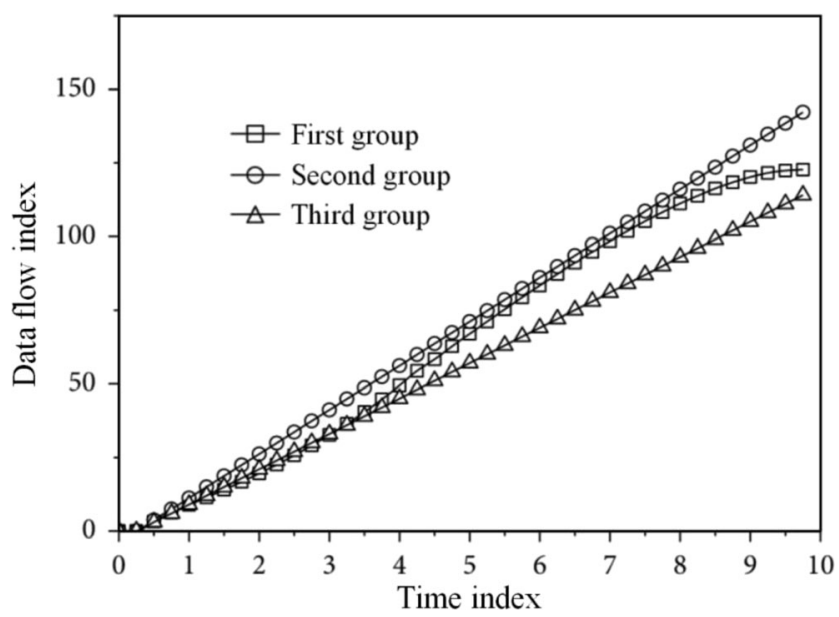

Fig. 6 Data impact over time

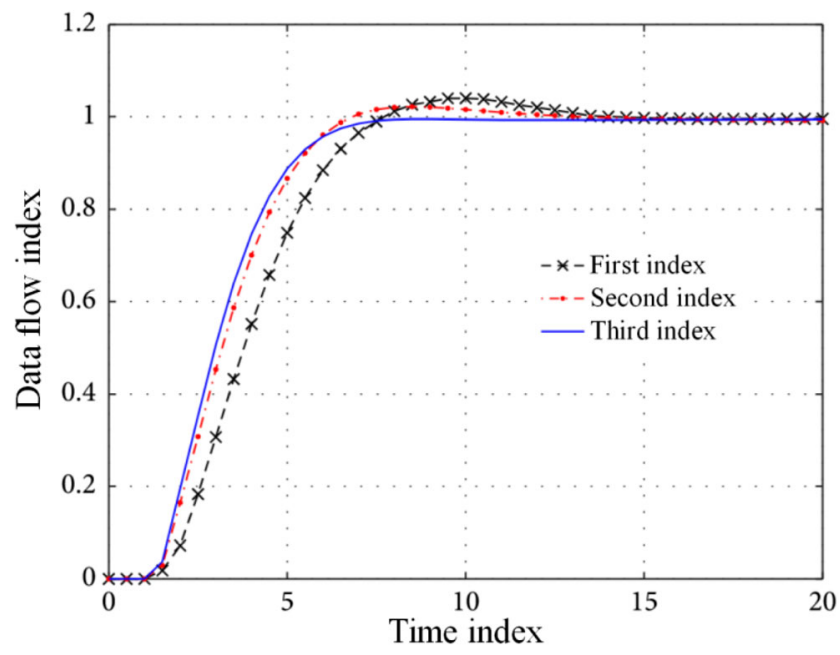

Fig. 7 Data impact over time

tests thrice and Fig. 7 represents all the results of the data collected.

Humanistic personality theory points out that human beings have a power of natural growth. People basically develop towards mature, socialized and self-fulfilling personality. Occupation comes into being and develops with the progress of human society and division of labor. It is the result of the development of social productive forces and scientific and technological innovation. From the student's point of view, students can find out their known and unknown knowledge and skills according to their majors ability charts. For those who are known, they can take exams and get credits instead of spending time studying. Self-actualization is a kind of transcendental or growth motivation, which is different from other ordinary people's lack of sexual motivation in quality and quantity. Because of the gradual establishment of the socialist market economy system, it has broken through the swaddle of the government to protect universities. The government is no longer able to cover all the universities. Stimulated by the market, universities themselves are not satisfied with the decentralized power of the government. The combination of professional and disciplinary content is designed to give today's students a thorough understanding of the various concepts that can be adapted to tomorrow's needs. The core of vocational education content is to teach vocational knowledge, develop vocational skills, and conduct vocational guidance. Self-realization is the full exploitation and utilization of human talents and potential. It is the completion of the mission, which is to fully grasp and recognize the intrinsic value of the individual.

Students will try their business during their school days, and invite experienced entrepreneurs to come to the school to give entrepreneurs a report. Wake up the professional education of teachers and students, and create a spirit of innovation and adventure by stimulating and guiding students' entrepreneurial enthusiasm and entrepreneurial desire. Many college 
Table 3 Survey of vocational education management curriculum

\begin{tabular}{llllll}
\hline & $\begin{array}{l}\text { Curriculum } \\
\text { view }\end{array}$ & $\begin{array}{l}\text { Course } \\
\text { resources }\end{array}$ & $\begin{array}{l}\text { Course } \\
\text { implementation }\end{array}$ & $\begin{array}{l}\text { Course } \\
\text { evaluation }\end{array}$ & $\begin{array}{l}\text { Course } \\
\text { reform }\end{array}$ \\
\hline $\begin{array}{l}\text { The average } \\
\text { score }\end{array}$ & 8 & 7 & 8 & 7 & 6 \\
\begin{tabular}{c} 
Correct rate $(\%)$ \\
\hline
\end{tabular} & 63.1 & 58.7 & 61.6 & 61.5 & 63.9 \\
\hline
\end{tabular}

teachers' knowledge in the curriculum field has the problem of narrow concept and insufficient understanding of the new curriculum. Lack of understanding of the current status and trends of the talent training curriculum reform. Table 3 shows the survey of vocational education management courses which simply means that curriculum view is score 8 , course resources score is 7 , course implementation score is 8 , course evaluation score is 7 , and course reform score is 6 which are evaluated based on the needs of an individual.

Vocational education management is based on the actual needs of human development and social development. The talent training evaluation indicators are divided into specific categories as shown in Table 4.

The key to the survival and development of the workplace is whether the ability is recognized by others. In order to eliminate the different effects of the original data dimension, data preprocessing is performed based on data mining. The standardization formula for recognition is:

$P=\frac{\sigma_{i}^{2}}{\sum_{i=1}^{m} \sigma_{i}^{2}}$

Need to meet:

$O_{t}=f\left(\sum_{i} T_{l i}-\theta_{l}\right)$

Define the distance formula:

$n=\sum_{i=1}^{R} P_{l} W_{l, j}+b$

Calculate the random consistency ratio:

$y_{i}=f\left(\sum_{j} w_{i j} x_{j}-\theta_{i}\right)$

From the perspective of the vertical structure of vocational education, the focus of vocational education will inevitably shift upwards, and the proportion of higher vocational education will gradually increase. The study finds that the purpose of the vocational education work experiment based on personality standard is to study the influence of different vector dimensions on the sentiment orientation judgment results. The experiment used the first and second sets of data sets. Table 5 gives the correct rate results for the first set of data sets under different feature dimensions. The trend of the correct rate under different feature dimensions is shown in Fig. 8.

The teaching research method model from the perspective of big data is to use the formal method. An abstract teaching method based on the concept of teaching effectiveness under the guidance of the theory of teaching effectiveness. The correction rules include a gradient evaluation of the candidate's mistakes, usual grades, test scores, and special hobbies. A node with a tight degree does not necessarily have a large degree, but this point plays a big role in data transmission. Reflects the core level of these nodes in the network. If these nodes are deliberately attacked, it may cause the entire network to crash. For example, the Table 6 is the degree of node degree, tightness, and data between parameters. Figure 9 shows the relationship between node degrees, tightness, and parameters.

Looking at the world's higher education, the state's management of higher education and the self-sponsorship of colleges and universities are indispensable for running higher education. However, to properly handle the relationship between the government and the university, it is necessary to establish an intermediary between the government and the university. The increasing degree of marketization of social employment has led to an increase in the frequency of social workers changing jobs. For those who are unknown, you can schedule your study time and progress according to your own situation. Students have a clear learning goal at the beginning of their studies and can choose the learning style they like. From the study it is understood that through vocational education, people have the skills to survive and develop that are similar to the results of another research study (Paessler,
Table 4 Division of talent training assessment

\begin{tabular}{llllll}
\hline Talent training evaluation parameters & $0-25$ & $25-30$ & $30-35$ & $40-45$ & $45-50$ \\
\hline Normalized value & 0.2 & 0.3 & 0.4 & 0.5 & 0.6 \\
\hline
\end{tabular}


Table 5 Semi-supervised experimental results based on vector length

\begin{tabular}{llllll}
\hline Feature dimension & 20 & 40 & 60 & 80 & 100 \\
\hline Correct rate(\%) & 73.64 & 74.37 & 75.71 & 83.96 & 82.56 \\
\hline
\end{tabular}

2015). It is not only the most direct goal of Vocational education, but also the livelihood value of Vocational education. There is a basic motivation in the personality system, that is, to keep realizing and strengthening all aspects of human beings. This realization motivation is inherent in human life, and is the driving force of existence and everyone's life. The differentiation of professional posts in technical level is on the one hand the enlargement of technical range of posts, on the other hand, the high shift of technical level of posts. A person with creative personality, his creativity will be subconsciously expressed anytime and anywhere. Not only will you show your creativity in your work, but also in your life.

\section{Conclusions}

With the rapid development of social economy in China, higher vocational education has made great progress both in scale and quantity. Active development of higher vocational education is not only an educational and academic issue, but also a strategic issue of social development and international competition. The development concept of higher vocational education still focuses on the level of social demand and economic development. The understanding and research of higher vocational education should not be confined to the interior of education. It needs to be explored and examined from many disciplines and perspectives, such as society and economy, science and technology and industry, history and culture, management and policy. If we cannot fully grasp the

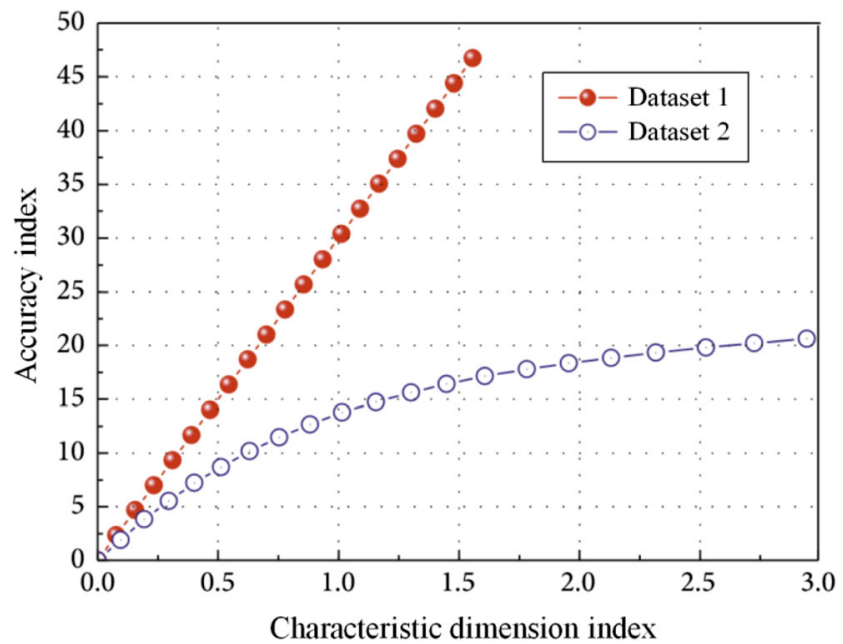

Fig. 8 Trends in the construction of vocational education patterns under different characteristic dimensions
Table 6 Node degree, tightness, and data between parameters

\begin{tabular}{llll}
\hline & Node degree & Tightness & Node parameter \\
\hline Node degree & 1 & 0.74 & 0.69 \\
Tightness & 0.67 & 1 & 0.54 \\
Node parameter & 0.71 & 0.71 & 1 \\
\hline
\end{tabular}

environmental characteristics and development trends of China's social change, we cannot fundamentally clarify and answer the essential issues in the development and reform of higher vocational education. In the historical period of economic globalization and internationalization of education. Higher vocational education has become an important part of international exchanges, cooperation and competition. The Need to enhance international competition awareness and international school philosophy has also become crucial. According to the actual situation, the scope of duties of the two-level higher education management committee must be confirmed in the form of legislation. In-depth discussion of the personality-based education model requires more joint efforts.

\section{Theoretical and Practical Implications}

The study contributed to the vocational education psychology and counselling psychology. It is found out that vocational higher secondary education, even today, focuses on economic development of the country which makes it difficult to reform the vocational education. On analyzing the current situation of China, the study discusses on developing a personality based education model which allows the vocational psychologists to understand the needs of the society and help the individuals to make right decisions with respect to their skills, knowledge and practical experience. Vocational psychologists argue that through vocational education, people have the skills to survive

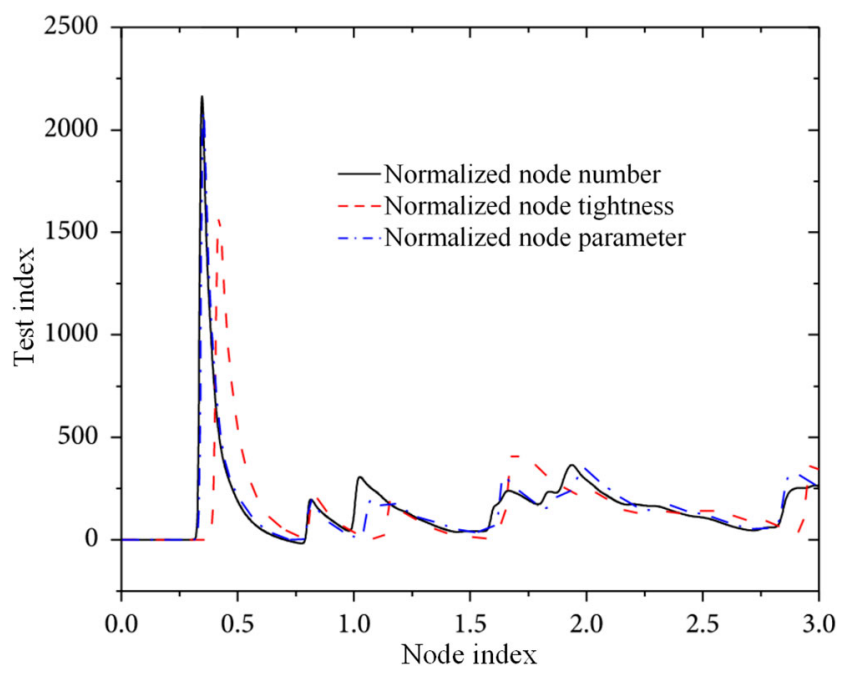

Fig. 9 Relationship between node degree, tightness, and parameters 
and develop a personality system which helps them to strengthen their personality. The next theoretical finding is that people with creativity will exhibit their skills at any time and at any place. Even while dealing with the life, a creative person always expresses his creativity either consciously or unconsciously. The findings of the study can be adopted by Vocational Education Institutions which will help the teachers, vocational psychologists as well who support the individuals to take important decisions of their life with respect to their career, skills, and competences.

Funding The Project Supported by National Social Science Fund of China (Grant No.AJA180008, Grant No. BJA190093).

Data Availability Data sharing is not applicable to this article as no new data were created or analyzed in this study.

\section{Declarations}

Conflict of Interest The authors declare that they have no conflict of interest.

Human and Animal Rights This article does not contain any studies with human or animal subjects performed by any of the authors.

Informed Consent Informed consent was obtained from all individual participants included in the study.

Open Access This article is licensed under a Creative Commons Attribution 4.0 International License, which permits use, sharing, adaptation, distribution and reproduction in any medium or format, as long as you give appropriate credit to the original author(s) and the source, provide a link to the Creative Commons licence, and indicate if changes were made. The images or other third party material in this article are included in the article's Creative Commons licence, unless indicated otherwise in a credit line to the material. If material is not included in the article's Creative Commons licence and your intended use is not permitted by statutory regulation or exceeds the permitted use, you will need to obtain permission directly from the copyright holder. To view a copy of this licence, visit http://creativecommons.org/licenses/by/4.0/.

\section{References}

Asplund, S. B., \& Kilbrink, N. (2016). Learning how (and how not) to weld: Vocational learning in technical vocational education [J]. Scandinavian Journal of Educational Research, 1-16.

Baartman, L., Gulikers, J., \& Dijkstra, A. (2013). Factors influencing assessment quality in higher vocational education[J]. Assessment \& Evaluation in Higher Education, 38(8), 978-997.

Blustein, D. L., Ali, S. R., \& Flores, L. Y. (2019). Vocational psychology: Expanding the vision and enhancing the impact. The Counseling Psychologist, 47(2), 166-221.

Cai, Z., Guan, Y., Li, H., Shi, W., Guo, K., Liu, Y., Li, Q., Han, X., Jiang, P., Fang, Z., \& Hua, H. (2015). Self-esteem and proactive personality as predictors of future work self and career adaptability: An examination of mediating and moderating processes [J]. Journal of Vocational Behavior, 86, 86-94.
Cevik, B., Perkmen, S., Alkan, M., \& Shelley, M. (2013). Who should study music education? A vocational personality approach[J]. Music Education Research, 15(3), 341-356.

Curtin, N., Stewart, A. J., \& Ostrove, J. M. (2013). Fostering academic self-concept: Advisor support and sense of belonging among international and domestic graduate students [J]. American Educational Research Journal, 50(1), 108-137.

Ding, Y., Salyers, K., Kozelka, S., \& Laux, J. (2015). Vocational personality traits in counselor education and school psychology students[J]. Journal of Employment Counseling, 52(4), 158-170.

Elffers, L., \& Oort, F. J. (2013). Great expectations: Students' educational attitudes upon the transition to post-secondary vocational education[J]. Social Psychology of Education, 16(1), 1-22.

Fouad, N. A., \& Iackson, M. A. (2013). Vocational psychology: Strengths. Handbook of vocational psychology: Theory, research, and practice, 305.

Fuller, A. (2015). Vocational education. International Encyclopedia of the Social \& Behavioral Sciences, 232-238.

Hastrup, L. H., Kongerslev, M. T., \& Simonsen, E. (2018). Low vocational outcome among people diagnosed with borderline personality disorder during first admission to mental health Services in Denmark: A Nationwide 9-year register-based study[J]. Journal of Personality Disorders, 1-15.

Heers, M., Van Klaveren, C., Groot, W., et al. (2014). The impact of community schools on student dropout in pre-vocational education [J]. Economics of Education Review, 41, 105-119.

Holtrop, D., Born, M. P., \& De Vries, R. E. (2015). Relating the spherical representation of vocational interests to the HEXACO personality model [J]. Journal of Vocational Behavior, 89, 10-20.

Jiang, Z. (2017). Proactive personality and career adaptability: The role of thriving at work [J]. Journal of Vocational Behavior, 98, 85-97.

Longo, Y., Gunz, A., Curtis, G. J., \& Farsides, T. (2016). Measuring need satisfaction and frustration in educational and work contexts: The need satisfaction and frustration scale (NSFS). Journal of Happiness Studies, 17(1), 295-317.

Niemi, A. M., \& Kurki, T. (2014). Getting on the right track? Educational choice-making of students with special educational needs in prevocational education and training[J]. Disability \& Society, 29(10), $1631-1644$.

Nilforooshan, P., \& Salimi, S. (2016). Career adaptability as a mediator between personality and career engagement [J]. Journal of Vocational Behavior, 94, 1-10.

Paessler, K. (2015). Sex differences in variability in vocational interests: Evidence from two large samples [J]. European Journal of Personality, 29(5), 568-578.

Perkmen, S., \& Sahin, S. (2013). Who should study instructional technology? Vocational personality approach[J]. British Journal of Educational Technology, 44(1), 54-65.

Potter, P., Lai, R. Z., Maturu, N., Stamberger, E., Stephens, N., \& Sze, P. (2011). Vocational education and training in China. Online verfügbar unter http://sites.fordschool.umich.edu/china-policy/files/ 2011/10/PP716 VET-Paper Final 042911-1.pdf.

Reichl, C., Wach, F. S., Spinath, F. M., Brünken, R., \& Karbach, J. (2014). Burnout risk among first-year teacher students: The roles of personality and motivation[J]. Journal of Vocational Behavior, 85(1), 85-92.

Rejeesh, M. R., \& Thejaswini, P. (2020). MOTF: Multi-objective Optimal Trilateral Filtering based partial moving frame algorithm for image denoising. Multimedia Tools and Applications, 79((3738)), 28411-28430.

Routledge, C., Wildschut, T., Sedikides, C. \& Juhl, J. (2013). Nostalgia as a resource for psychological health and well-being. Social and Personality Psychology Compass, 7(11), 808-818.

Schulte, B. (2013). Unwelcome stranger to the system: Vocational education in early twentieth-century China. Comparative Education, 49(2), 226-241. 
Selvarajan, T. T., Singh, B., \& Cloninger, P. A. (2016). Role of personality and affect on the social support and work family conflict relationship [J]. Journal of Vocational Behavior, 94, 39-56.

Sheldon, P. (2005). Employability skills and vocational education and training policy in, Australia: An analysis of employer association agendas[J]. Asia Pacific Journal of Human Resources, 43(3), 404 425.

Sovet, L., Park, S. A., \& Jung, S. (2014). Validation and psychometric properties of academic major satisfaction scale among Korean college students[J]. Social Indicators Research, 119(2), 1121-1131.

Stewart, V. (2015). Made in China: Challenge and innovation in China's vocational education and training system. International Comparative Study of Leading Vocational Education Systems. National Center on Education and the Economy.

Sundararaj, V. (2016). An Efficient Threshold Prediction Scheme for Wavelet Based ECG Signal Noise Reduction Using Variable Step Size Firefly Algorithm. International Journal of Intelligent Engineering and Systems, 9, 117-126.

Sundararaj, V. (2019a). Optimal Task Assignment in Mobile Cloud Computing by Queue Based Ant-Bee Algorithm. Wireless Personal Communications, 104, 173-197.

Sundararaj, V. (2019b). Optimised denoising scheme via oppositionbased self-adaptive learning PSO algorithm for wavelet-based ECG signal noise reduction. International Journal of Biomedical Engineering and Technology, 31, 325.

Sundararaj, V., \& Rejeesh, M. R. (2021). A detailed behavioral analysis on consumer and customer changing behavior with respect to social networking sites. Journal of Retailing and Consumer Services, 58, 102190

Taylor, J. L., \& Mailick, M. R. (2013). A longitudinal examination of 10year change in vocational and educational activities for adults with autism Spectrum disorders[J]. Developmental Psychology, 50(3), 699-708.

Tiwari, M., Tiwari, T., Santhose, S. S., Mishra, L., Rejeesh M, R., \& Sundararaj, V. (2021). Corporate social responsibility and supply chain: A study for evaluating corporate hypocrisy with special focus on stakeholders. International Journal of Finance \& Economics. https://doi.org/10.1002/ijfe.2483.

Tolentino, L. R., Garcia, P. R. J. M., Lu, V. N., Restubog, S. L. D., Bordia, P., \& Plewa, C. (2014). Career adaptation: The relation of adaptability to goal orientation, proactive personality, and career optimism[J]. Journal of Vocational Behavior, 84(1), 39-48.

Venuleo, C., Mossi, P., \& Salvatore, S. (2014). Educational subculture and dropping out in higher education: A longitudinal case study [J]. Studies in Higher Education, 41(2), 1-22.

Volodina, A., Nagy, G., \& Olaf, K. (2015). Success in the first phase of the vocational career: The role of cognitive and scholastic abilities, personality factors, and vocational interests.[J]. Journal of Vocational Behavior, 91, 11-22.

Wu, C. H. (2016). Personality change via work : A job demand-control model of big-five personality changes. [J]. Journal of Vocational Behavior, 92, 57-166.

Xiong, J. (2011). Understanding higher vocational education in China: Vocationalism vs Confucianism. Frontiers of Education in China, 6(4), 495-520.

Yu, X. (2005). A comparative review on Chinese vocational education and training system. The Online Journal of New Horizons in Education, 3(2), 1-7.

Yaun, J. F. (2013). A study to determine whether a relationship exists between attending a public, two-year community college in the United States with or without campus housing and the retention of first-year students.

Zacher, H. (2014). Career adaptability predicts subjective career success above and beyond personality traits and core self-evaluations $[\mathrm{J}]$. Journal of Vocational Behavior, 84(1), 21-30.

Publisher's Note Springer Nature remains neutral with regard to jurisdictional claims in published maps and institutional affiliations. 